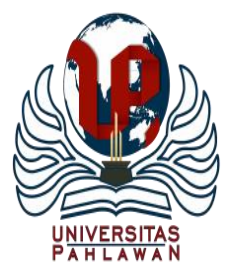

Edukatif : Jurnal Ilmu Pendidikan Volume 3 Nomor 5 Tahun 2021 Halm 2040 - 2047

EDUKATIF: JURNAL ILMU PENDIDIKAN

Research \& Learning in Education

https:/ledukatif.org/index.php/edukatif/index

\title{
Peningkatan Hasil Belajar Siswa Sekolah Dasar Melalui Model Pembelajaran Problem Based Learning
}

\author{
Syarifa Rahma Amalia $^{1 凶}$, Veryliana Purnamasari $^{2}$, Darsimah $^{3}$ \\ Universitas PGRI Semarang, Indonesi ${ }^{1,2}$ \\ Sekolah Dasar Negeri Wonotingal Semarang, Indonesia ${ }^{3}$ \\ E-mail : syarifarahmaa@gmail.com ${ }^{1}$, verylianapurnamasari@gmail.com ${ }^{2}$, \\ darsimahsendangmulyo04@gmail.com ${ }^{3}$
}

\begin{abstract}
Abstrak
Penelitian ini bertujuan untuk mendeskripsikan penerapan model Problem Based Learning terhadap peningkatan hasil belajar siswa. Penelitian dikhususkan pada Tema 9 Benda-Benda di Sekitar Kita muatan Bahasa Indonesia subtema 1 pembelajaran 1, 3,5, dan subtema 2 pembelajaran 1, 3 dan 5.Model Problem Based Learning merupakan model pembelajaran dengan menyajikan pertanyaan atau keadaan berbasis masalah, untuk mengasah kemampuan berpikir siswa. Penelitian tindakan kelas ini telah dilaksanakan di kelas VB SDN Wonotingal Semarang dengan subjek penelitian 30 siswa. Penelitian ini telah berlangsung dalam tiga siklus. Variabel bebas dalam penelitian ini ialah model Problem Based Learning, sedangkan variabel terikatnya ialah hasil belajar siswa. Teknik pengumpulan data dilakukan dengan teknik tes, wawancara, dan dokumentasi. Analisis data yang digunakan merupakan analisis data kuantitatif.Siklus I hasil belajar memperoleh nilai rata-rata 62,5 termasuk kriteria perlu bimbingan. Siklus II hasil belajar memperoleh nilai ratarata 69 termasuk kriteria perlu bimbingan. Siklus III hasil belajar memperoleh nilai rata-rata 83 termasuk kriteria baik. Berdasarkan hasil penelitian tindakan kelas yang telah dilaksanakan pada kelas VB SDN Wonotingal Semarang, disimpulkan bahwa hasil belajar siswa dapat meningkat melalui model pembelajaran Problem Based Learning pada tema 9 Benda-Benda di Sekitar Kita kelas VB SDN Wonotingal Semarang.
\end{abstract}

Kata Kunci: Penelitian Tindakan Kelas, Problem Based Learning, Hasil Belajar Siswa.

\begin{abstract}
This research described implementation of Problem Based Learning to student learning outcomes. This research was specialized on theme 9 - objects arounds us with Indonesian language study contents, subtheme 1- material 1, 3, and 5, and subtheme 2- material 1, 3, and 5.Problem Based Learning model is a learning model presenting question and condition based problem to train thinking ability ot the students. This classroom action research was conducted for fifth "B" graders of Wonotingal Primary School Semarang, consisting of 30 students. It lasted in three cycles. The independent status were Problem Based Learning. The dependent variables were student learning outcomes. The data collection technique were test, interview, and documentation. The data analysis were quantitative data analysis. The students' learning outcomes improved in cycle I, from 62.5 into 69 in cycle II dan 83 in cycle III. It is concluded that Student Learning Outcomes could be improved through Problem Based Learning for Persuasion Text Materials on the Themed 9 Objects Around Us for Fifth "B" Graders of Wonotingal Primary School Semarang. Therefore, it is suggested while implementating the learning model, teacher should be more innovative so that students would be more eager and active in learning.
\end{abstract}

Keywords: Classroom Action Research;Problem Based Learning;Student Learning Outcomes.

Copyright (c) 2021 Syarifa rahma amalia, Veryliana Purnamasari,

Darsimah

$\triangle \triangle$ Corresponding author
Email $\quad$ syarifarahmaa@gmail.com
DOI $\quad:$ https://doi.org/10.31004/edukatif.v3i5.747

ISSN 2656-8063 (Media Cetak)

ISSN 2656-8071 (Media Online) 
2041 Peningkatan Hasil Belajar Siswa Sekolah Dasar Melalui Model Pembelajaran Program Based Learning Syarifa Rahma Amelia, Veryliana Purnamasari, Darsimah

DOI : https://doi.org/10.31004/edukatif.v3i5.747

\section{PENDAHULUAN}

Secara formal dan institusinal, sekolah dasar masuk pada kategori pendidikan dasar. (Susanto, 2016) menyatakan sekolah dasar masuk kategori pada pendidikan dasar. Sejak tahun 1945, kurikulum di Indonesia telah berulang kali diperbaharui dan disempurnakan. Prinsip utama yang paling mendasar pada kurikulum 2013 adalah penekanan pada kemampuan guru mengimplementasikan proses pembelajaran yang otentik, menantang dan bermakna bagi peserta didik sehingga dengan demikian dapatlah berkembang potensi peserta didik sesuai dengan apa yang diharapkan oleh tujuan pendidikan nasional. Proses pembelajaran yang dilakukan seharusnya dilengkapi dengan aktivitas mengamati, menanya, mengolah, menyajikan, menyimpulkan, dan mencipta (Kurniaman \& Noviana, 2017). Namun, masih banyak guru yang belum belum mampu mengimplementasikan kurikulum 2013 itu dalam pembelajaran. Tema 9 "Benda-benda di Sekitar Kita" didalamnya termuat tentang teks persuasif yang menuntut siswa untuk mengembangkan kreativitas dan imajinasinya untuk menuangkan gagasannya ke dalam bentuk tulisan, siswa cenderung bingung tentang apa yang hendak ditulis dalam sebuah teks. Teks adalah sebuah wacana lisan dalam bentuk tulisan. Disempurnakan oleh Rahma \& Priswati (2019, p. 181) yang menyatakan bahwa teks persuasi merupakan teks tentang pernyataan-pernyataan yang berisi ajakan atau bujukan untuk mendorong peserta didik mengikuti keinginan dari penulis.

Octavia et al (2020) mengungkapkan keterampilan menulis merupakan keterampilan berbahasa yang paling kompleks dan sangat penting sebagai penunjang keberhasilan proses belajar-mengajar, karena menulis merupakan keterampilan menuangkan dan mengembangkan ide atau gagasan dari hasil proses menyimak, berbicara, ataupun membaca. Sejalan dengan Achmad \& Wintala (2015, p. 21) yang menambahkan bahwa salah satu tujuan pembelajaran Bahasa Indonesia di lingkup dunia akademik khususnya dan masyarakat pada umumnya adalah supaya anak didik dan masyarakat bisa mampu menghayati karya sastra Indonesia yang fungsinya dapat memberikan inspirasi, edukasi, dan rekreasi yang sehat. Salah satu pembelajaran tersebut adalah teks persuasi. Sejalan dengan itu, diera digital saat ini perkembangan tulisan di media sosial sangat cepat untuk menyampaikan gagasan, menjual barang atau mengkritisi suatu peristiwa sehingga sangat dibutuhkan kemampuan menulis teks persuasi. Diharapkan siswa dapat menganalisis teks persuasi dan membuat tulisan tentang teks persuasi.

Berdasarkan hasil observasi pra penelitian di kelas VB SDN Wonotingal Semarang pada bulan Februari 2021 sampai Maret 2021 menunjukkan bahwa pelaksanaan pembelajaran kurikulum 2013 dalam kegiatan pembelajaran, ditemukan siswa kurang menguasai kompetensi dasar pengetahuan muatan pembelajaran Bahasa Indonesia terutama saat memahami bacaan, siswa hanya membaca dan menuangkan imajinasinya secara apa adanya tidak dikembangkan secara kreatif yang menyebabkan kemampuan berpikir kritis siswa rendah, kurang optimal, dalam menanggapi permasalahan dan memecahkan suatu masalah seperti soal yang diberikan guru dan berakibat pada hasil belajarnya menjadi rendah. Hal tersebut terlihat dari 30 siswa pada muatan pembelajaran Bahasa Indonesia tidak tuntas sebanyak 21 siswa yang mendapat nilai dibawah KKM. Dari hasil observasi menunjukkan bahwa hasil belajar siswa rendah. Hasil belajar siswa rendah, juga dipengaruhi keaktifan siswa dalam pembelajaran rendah dan guru kurang kreatif menerapkan model dan mengembangkan media pembelajaran.

Hal yang menjadikan hasil belajar siswa kelas V SDN Wonotingal Semarang rendah adalah penguasaan materi. Terutama pada materi teks yang membutuhkan pemikiran yang kreatif namun siswa hanya membaca dari buku sehingga menyimpulkan dengan mengutip apa adanya didalam buku tersebut bukan dengan bahasanya sendiri selain itu, siswa juga membuat isi teks dengan menuangkan imajinasinya secara apa adanya tidak dikembangkan secara kreatif. Guru kurang kreatif dalam menyampaikan materi pembelajaran secara lebih luas dan umpan balik terhadap siswa kurang. Selama proses belajar mengajar siswa terlihat cukup aktif dengan kegiatan diskusi dan tanya jawab antara siswa dengan guru, tetapi dalam menjawab pertanyaan guru, 
2042 Peningkatan Hasil Belajar Siswa Sekolah Dasar Melalui Model Pembelajaran Program Based Learning Syarifa Rahma Amelia, Veryliana Purnamasari, Darsimah

DOI : https://doi.org/10.31004/edukatif.v3i5.747

siswa yang pandai cenderung mendominasi dalam menjawabnya, sedangkan siswa yang merasa kurang pandai, cenderung malu-malu dalam menyampaikan gagasannya, siswa kurang antusias dalam mengikuti pembelajaran yang didominasi dengan bacaan dan hafalan, dan model pembelajaran yang digunakan oleh guru sudah inovatif, tetapi dalam pelaksanaannya kurang optimal. Penerapan model pembelajaran menjadikan suasanan proses pembelajaran tidak membosankan dan dapat membuat siswa aktif dalam kegiatan pembelajaran.

Berdasarkan kondisi tersebut, diperlukan alternatif tindakan untuk meningkatkan hasil belajar siswa dalam pembelajaran. Dalam hal ini peneliti merancang pembelajaran yang siswa terlihat aktif dalam berdiskusi, menganalisis dan mengemukakan gagasannya.

Murtono (2017, p. 213) menyatakan bahwa model pembelajaran problem based learning ini merupakan model yang efektif untuk pengajaran proses berpikir tingkat tinggi. Dikuatkan oleh Yosepina (2020) mengatakan bahwa pembelajaran tematik merupakan pembelajaran yang sangat bermakna bagi siswa, karena siswa lebih banyak terlibat dalam proses pembelajaran dan pembelajaran benar-benar dikait dengan kehidupan nyata siswa. Pembelajaran berbasis masalah menekankan masalah kehidupannya yang beramakna bagi siswa dan peran guru dalam menyajikan masalah, mengajukan pertanyaan, dan memfasilitasi penyelidikan dan dialog sehingga dengan penerapan model ini, membantu siswa untuk memahami pembelajaran tema peristiwa dalam kehidupan dikarenakan model ini menekankan pemecahan masalah dan mendukung dalam meningkatkan kemampuan berpikir kritis siswa. Berdasarkan kelebihan dari model problem based learning yang telah dipaparkan, diduga siswa dapat meningkatkan hasil belajarnya. Maka dari itu, peneliti memilih model problem based learning untuk membuktikan teori ini. Tetapi lain halnya jika pembelajaran problem based learning diajarkan secara daring. Salah satu peran guru yaitu sebagai fasilitator yang berperan dalam memberikan pelayanan untuk memudahkan siswa dalam proses pembelajaran (Syupriyanti et al., 2019). Guru dituntut untuk dapat melaksanakan pembelajaran melalui daring di masa pandemi COVID-19 ini. Pembelajaran daring bukan sekedar materi yang dipindah melalui media internet, bukan juga sekedar tugas dan soal-soal yang dikirimkan melalui aplikasi sosial media, pembelajaran daring harus direncanakan, dilaksanakan, serta dievaluasi sama halnya dengan pembelajaran yang terjadi di kelas (Yunitasari \& Hanifah, 2020).

Berdasarkan uraian di atas, maka dalam upaya mencapai ke arah tujuan penelitian ini, yaitu untuk meningkatkan hasil belajar muatan pembelajaran Bahasa Indonesia, maka penulis melakukan penelitian untuk mengetahui dan mendeskripsikan penerapan model Problem Based Learning terhadap peningkatan hasil belajar siswa.

\section{METODE PENELITIAN}

Jenis penelitian yang digunakan yaitu Penelitian Tindakan Kelas (PTK). Penelitian tindakan kelas merupakan penelitian kasus disuatu kelas yang hasilnya tidak untuk digeneralisasikan, maka analisis data cukup dengan mendeskripsikan data yang terkumpul (Nafiah \& Suyanto, 2014). Desain penelitian ini yaitu model Kemmis dan Mc Taggart, meliputi empat tahapan diantaranya perencanaan, pelaksanaan tindakan, observasi dan refleksi. Subjek penelitian ini yaitu siswa kelas VB SDN Wonotingal Kabupaten Semarang dengan jumlah 30 siswa, jumlah siswa perempuan 14 dan laki-laki 16 siswa. Penelitian dilaksanakan dalam 3 siklus dan masing-masing siklus terdiri dari 2 pertemuan. Siklus I dilaksanakan pada tanggal 29 Maret-01 April 2021, siklus II pada tanggal 06 April-09 April 2021, dan siklus III pada tanggal 15 April-19 April 2021. Penelitian dilakukan pada tema 9 Benda-Benda di Sekitar Kita, subtema 1 Benda Tunggal dan Campuran serta subtema 2 Benda dalam Kegiatan Ekonomi, masing-masing pada pembelajaran 1,3, dan 5.

Teknik yang digunakan dalam penelitian ini yaitu tes. Tes merupakan salah satu upaya pengukuran terencana yang digunakan oleh guru untuk mencoba menciptakan kesempatan bagi siswa dalam 
2043 Peningkatan Hasil Belajar Siswa Sekolah Dasar Melalui Model Pembelajaran Program Based Learning Syarifa Rahma Amelia, Veryliana Purnamasari, Darsimah

DOI : https://doi.org/10.31004/edukatif.v3i5.747

memperlihatkan hasil prestasi mereka yang berkaitan dengan tujuan yang telah ditentukan (Kurniawati, 2018). Tes dalam penelitian ini yaitu tes pra siklus dan tes evaluasi akhir pertemuan. Tes pra siklus dilaksanakan pada tanggal 18 Februari 2021. Tes yang dilaksanakan pada setiap pertemuan baik siklus I siklus II, maupun siklus III dengan model Problem Based Learning. Tes evaluasi untuk mengukur hasil belajar siswa aspek pengetahuan siswa terdiri dari 5 soal pilihan ganda.. Teknik analisis data penelitian ini menggunakan analisis data kuantitatif. Data kuantitatif berupa tingkat pemahaman kognitif dan berbentuk bilangan.

Hasil tes siswa dianalisis dengan mengacu tabel kriteria menurut KKM SDN Wonotingal Semarang yang telah disesuaikan dengan panduan penilaian SD kurikulum 2013 yang dapat dilihat pada Tabel 1.

Tabel 1. Kriteria Hasil Belajar Siswa

\begin{tabular}{llll}
\hline No. & Nilai & Kriteria & Predikat \\
\hline 1. & $91<\mathrm{x} \leq 100$ & Sangat Baik & A \\
\hline 2. & $82<\mathrm{x} \leq 91$ & Baik & $\mathrm{B}$ \\
\hline 3. & $73 \leq \mathrm{x} \leq 82$ & Cukup & $\mathrm{C}$ \\
\hline 4. & $\mathrm{x}<73$ & Perlu Bimbingan & $\mathrm{D}$ \\
\hline
\end{tabular}

Cara menghitung nilai rata-rata klasikal menggunakan rumus:

$$
\begin{gathered}
\text { Nilai }=\frac{\text { jumlah nilai siswa }}{\text { jumlah seluruh siswa }} \times 100 \\
\text { Sumber: (Panduan Penilaian Kurikulum 2013, 2016, p. 56) }
\end{gathered}
$$

\section{HASIL DAN PEMBAHASAN PENELITIAN}

Hasil penelitian pra siklus yang telah dilakukan pada siswa kelas VB SDN Barongan, diperoleh nilai rata-rata klasikal dengan nilai 57,76 dengan kriteria perlu bimbingan. Pada siklus I pertemuan I hasil belajar siswa diperoleh nilai rata-rata klasikal 60,33 dengan kriteria perlu bimbingan, pada siklus I pertemuan II hasil belajar siswa diperoleh nilai rata-rata klasikal 64,67 dengan kriteria perlu bimbingan, sehingga hasil belajar siswa siklus I diperoleh nilai rata-rata klasikal 62,5 dengan kriteria perlu bimbingan. Pada siklus I siswa sudah berani bertanya kepada guru akan tetapi masih banyak yang malu-malu dalam memberikan penjelasan sederhana sehingga terbata-bata, siswa masih kesulitan dalam membuat keputusan dengan cepat itupun harus ditunjuk guru, dan siswa tidak mempertimbangkan hasil diskusi kelompoknya dengan mengkroscek kembali ketika pembelajaran kelompok di whatsapp

Problem Based Learning mengarahkan siswa untuk membedakan antara informasi yang baik dan buruk, serta dapat mengambil keputusan yang tepat dalam menganalisis argumen (Fakhriyah et al., 2016). Hasil belajar siswa meningkat pada siklus II, pada siklus II pertemuan I hasil belajar siswa diperoleh nilai rata-rata klasikal 67,33, pada siklus II pertemuan II hasil belajar siswa diperoleh nilai rata-rata klasikal 70,67 dengan kriteria perlu bimbingan, sehingga hasil belajar siswa siklus II diperoleh nilai rata-rata klasikal 69 dengan kriteria perlu bimbingan. Pada siklus II Saat siswa akan menjawab pertanyaan guru suara noise karena microfone banyak yang hidup dan siswa banyak yang mematikan kameranya.

Pada siklus III hasil belajar siswa telah mengalami peningkatan, pada siklus III pertemuan I hasil belajar siswa diperoleh nilai rata-rata klasikal 80, pada siklus III pertemuan II hasil belajar siswa diperoleh nilai rata-rata klasikal 86 dengan kriteria baik, sehingga hasil belajar siswa siklus III diperoleh nilai rata-rata klasikal 83 dengan kriteria baik. Rekapitulasi hasil hasil belajar siswa dapat dilihat di Gambar 1. 
2044 Peningkatan Hasil Belajar Siswa Sekolah Dasar Melalui Model Pembelajaran Program Based Learning Syarifa Rahma Amelia, Veryliana Purnamasari, Darsimah

DOI : https://doi.org/10.31004/edukatif.v3i5.747

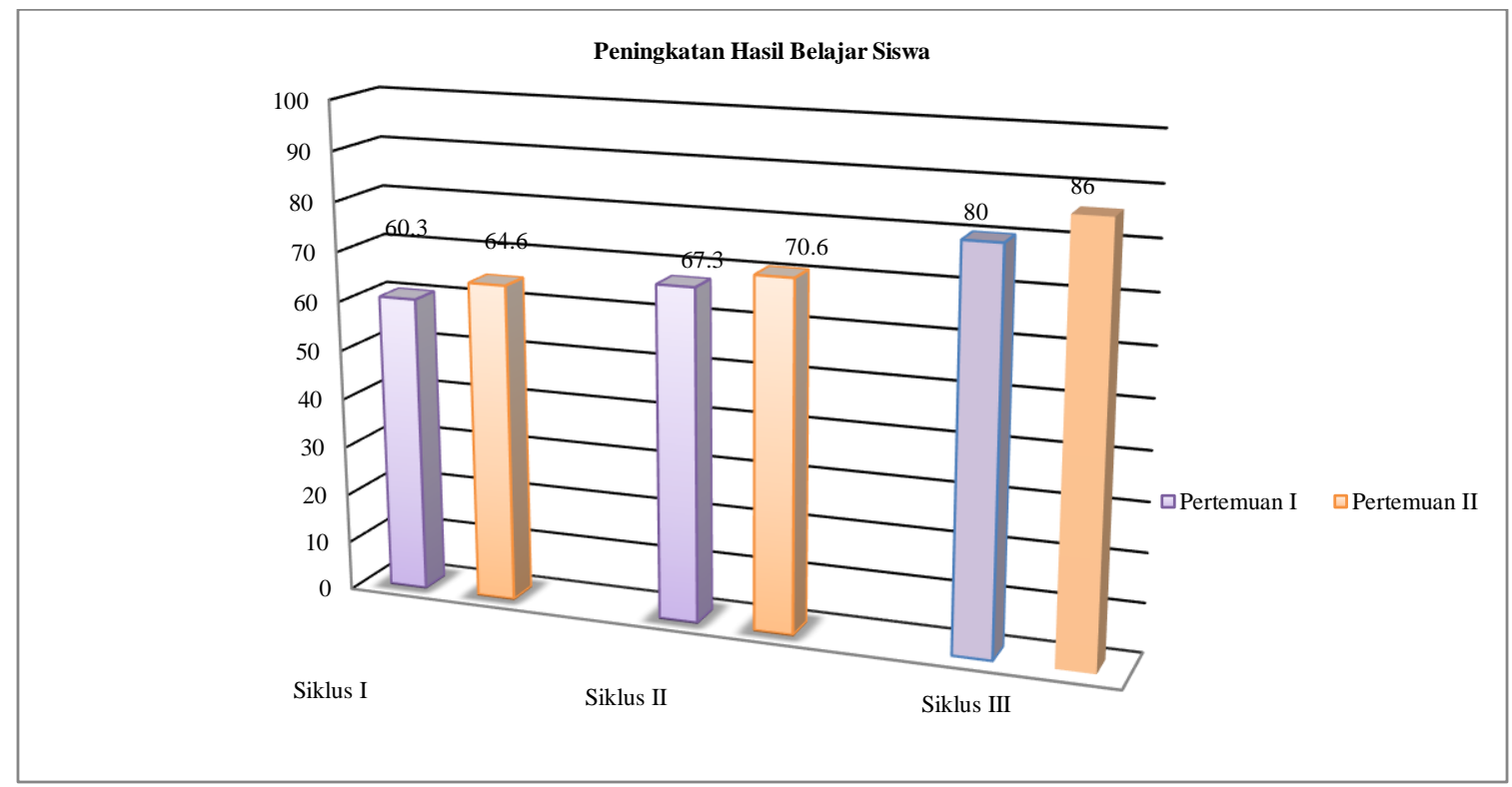

Gambar 1. Diagram Peningkatan Hasil Belajar Siswa.

Penelitian tindakan kelas yang telah dilaksanakan pada 29 Maret 2021 hingga 19 April 2021 menunjukkan bahwa hasil belajar siswa dapat ditingkatkan dengan menerapkan model pembelajaran Problem Based Learning pada Tema 9 Benda-Benda di Sekitar Kita kelas VB SDN Wonotingal Semarang. Hasil belajar siswa diukur dari aspek pengetahuan pada kegiatan prasiklus diperoleh nilai 57.7 dengan kriteria ketuntasan klasikalnya perlu bimbingan. Perolehan hasil tes prasiklus menunjukkan 9 siswa telah mencapai nilai $\geq 73$ dengan kriteria sangat baik. Sedangkan 21 siswa lainnya mendapatkan nilai $<73$ dengan kriteria perlu bimbingan. Nilai rata-rata klasikal yang didapatkan yaitu 57.7 dengan nilai tertinggi 100 dan nilai terendah 0. Rendahnya ketuntasan belajar klasikal dikarenakan siswa belum fokus terhadap proses pembelajaran sehingga ada siswa yang belum memahami materi yang disampaikan guru. Hasil tes akhir siklus I pertemuan I diperoleh 11 siswa telah mencapai nilai $\geq 73$ dengan kriteria cukup dan sangat baik, sedangkan 19 siswa lainnya mendapatkan nilai <73 dengan kriteria perlu bimbingan. Pada pertemuan II, diperoleh 21 siswa telah mencapai nilai $\geq 73$ dengan kriteria cukup dan sangat baik, sedangkan 9 siswa lainnya mendapatkan nilai $<73$ dengan kriteria perlu bimbingan. Nilai rata-rata klasikal yang didapatkan yaitu 62.5 dengan kriteria perlu bimbingan serta nilai tertinggi 100 dan nilai terendah 0 .

Rendahnya nilai rata-rata klasikal dikarenakan siswa belum fokus terhadap proses pembelajaran, terdapat beberapa siswa yang tidak memperhatikan dan mengacuhkan penjelasan dari guru yang sedang memberikan penjelasan, ada juga yang mengantuk dan menopang dagu sehingga ada siswa yang kurang berkonsentrasi dan belum memahami materi yang disampaikan oleh guru. Pada awal pembelajaran siswa telah menerima cerita dan rumusan masalah dalam bentuk pertanyaan dari guru melalui untuk memancing kemampuan berpikir mereka. Siswa sudah cukup antusias dalam menyampaikan hipotesis. Kemudian guru membimbing siswa untuk menemukan jawaban. Kemudian guru membimbing siswa untuk menemukan jawaban dengan melakukan diskusi. Guru berperan membantu siswa yang mengalami kesulitan dalam memahami pertanyaan dan melaksanakan diskusi kelompok. Hal ini sejalan dengan Rahmat, (2018, p. 146) yang menyatakan bahwa model PBL merupakan salah satu model pembelajaran dimana authenticassesment (penalaran yang nyata atau konkret) dapat diterapkan secara komprehensif, sebab di dalamnya terdapat unsur menemukan masalah dan sekaligus memecahkannya.

Hasil belajar siswa pada siklus II mengalami peningkatan. Siswa sudah dapat memahami materi dengan jelas, yang ditunjukkan dari hasil belajar siswa diakhir siklus yang meningkat. Hasil tes akhir siklus II pertemuan I diperoleh 21 siswa telah mencapai nilai $\geq 73$ dengan kriteria cukup dan sangat baik, sedangkan 9 
2045 Peningkatan Hasil Belajar Siswa Sekolah Dasar Melalui Model Pembelajaran Program Based Learning Syarifa Rahma Amelia, Veryliana Purnamasari, Darsimah

DOI : https://doi.org/10.31004/edukatif.v3i5.747

siswa lainnya mendapatkan nilai $<73$ dengan kriteria perlu bimbingan. Pada pertemuan II, diperoleh 24 siswa telah mencapai nilai $\geq 73$ dengan kriteria cukup dan sangat baik, sedangkan 6 siswa lainnya mendapatkan nilai $<73$ dengan kriteria perlu bimbingan. Nilai rata-rata klasikal yang didapatkan yaitu 69 dengan kriteria perlu bimbingan serta nilai tertinggi 100 dan nilai terendah 0. Kekurangan di siklus II terdapat pada siswa yang masih malu-malu dalam menyampaikan pendapatnya ketika tanya jawab dengan guru.

Hasil belajar mengalami peningkatan disiklus III. Hal ini ditunjukkan dengan siswa yang lebih berpartisipasi aktif dalam mengikuti pembelajaran dengan langkah-langkah model pembelajaran Problem Based Learning. Siswa sudah dapat memahami materi dengan jelas, yang ditunjukkan dari hasil belajar siswa diakhir siklus yang meningkat. Hasil tes akhir siklus III pertemuan I diperoleh 28 siswa telah mencapai nilai $\geq 73$ dengan kriteria cukup dan sangat baik, sedangkan 2 siswa lainnya mendapatkan nilai <73 dengan kriteria perlu bimbingan. Pada pertemuan II, diperoleh 28 siswa telah mencapai nilai $\geq 73$ dengan kriteria cukup dan sangat baik, sedangkan 2 siswa lainnya mendapatkan nilai $<73$ dengan kriteria perlu bimbingan. Nilai rata-rata klasikal yang didapatkan yaitu 83 dengan kriteria baik serta nilai tertinggi 100 dan nilai terendah 60. Dua siswa yang belum tuntas disiklus III pertemuan II yaitu DXG dan NIP mendapatkan nilai $\leq 73$ dengan kriteria perlu bimbingan. Kekurangan di siklus III terdapat pada siswa kurang konsentrasi terlihat dari pandangannya yang kosong dan tidak memperhatikan guru ketika mengajar.Peningkatan hasil belajar siswa dari tes prasiklus, siklus I, siklus II, dan siklus III menunjukkan bahwa penerapan model pembelajaran Problem Based Learning mengalami perkembangan.

Model pembelajaran Problem Based Learning memberikan kesempatan kepada siswa untuk berpartisipasi aktif dalam proses pembelajaran. Siswa semakin antusias dalam menunjukkan kemampuan berpikir. Adanya penguatan pembelajaran yang diberikan oleh guru berdampak positif dalam pembelajaran di kelas serta mengoptimalkan kemampuan berpikir siswa. Siswa lebih termotivasi untuk berpikir, menjawab, dan mengajukan pertanyaan. Berbagai bentuk apresiasi seperti ucapan terimakasih dan reward berperan penting dalam pembelajaran. Hal tersebut didukung oleh Kirom $(2017$, p. 72 ) yang melihat bahwa guru mempunyai tiga fungsi utama dalam pembelajaran, yaitu sebagai perencana (planner), pelaksana dan pengelola (organizer) dan penilai (evaluator). Dikuatkan dengan penelitian yang dilakukan oleh Haryanti (2017, p. 61) yang memperoleh kesimpulan bahwa pembelajaran berbasis masalah dapat meningkatkan kemampuan berpikir kritis siswa. Berpikir kritis itu sangat penting bagi siswa, seorang siswa bisa memahami kondisi suatu daerah dengan kendala yang ada, kendala ini bisa diselesaikan jika dalam proses berpikir kritis siswa mempunyai kesadaran dalam membuat, memandu, sera mengukur apa yang akan dipelajari (Evi \& Indarini, 2021). Pembelajaran dengan Problem Based Learning memberikan pengalaman belajar yang bermakna bagi siswa yang difokuskan untuk menjebatani siswa agar memperoleh pengalaman belajar dalam mengorganisasikan, meneliti, dan memecahkan masalah-masalah kehidupan yang kompleks sehingga lebih memahami materi dan sesuai dengan tujuan dari kurikulum 2013, seperti yang telah diungkapkan oleh Nada (2018, p. 217) bahwa dalam kurikulum 2013 proses belajar berpusat pada siswa (student centered).

Penerapan model pembelajaran Problem Based Learning memberikan dampak positif terhadap meningkatnya hasil belajar siswa kelas VB SDN Wonotingal Semarang pada tema Benda-Benda di Sekitar Kita. Pembelajaran yang komunikatif bersifat dua arah antara guru dan siswa menumbuhkan rasa percaya diri siswa sehingga hasil belajar siswa meningkat, yang membuktikan bahwa model pembelajaran Problem Based Learning adalah model yang tepat dalam meningkatkan hasil belajar siswa. Hal ini berbeda dengan penelitian yang telah dilakukan oleh Suardin \& Andriani (2021, p. 234) yang mendapatkan perbedaan signifikan antara hasil belajar siswa yang menggunakan model pembelajaran Problem Solving atau yang berbasis pemecahan masalah dimana nilai rata-rata kelompok yang diberi perlakuan model pembelajaran Problem Solving lebih rendah dibandingkan dengan kelompok yang diberi perlakuan dengan model pembelajaran Teams Games Tournament, hal itu dapat dilihat dari nilai sig (2-tailed) 0,00 lebih kecil atau sama dengan 0,05 $(0,00 \leq 0,05)$. Hal ini dikarenakan pelaksanaan penelitian ini dilaksanakan secara daring 
2046 Peningkatan Hasil Belajar Siswa Sekolah Dasar Melalui Model Pembelajaran Program Based Learning Syarifa Rahma Amelia, Veryliana Purnamasari, Darsimah

DOI : https://doi.org/10.31004/edukatif.v3i5.747

sehingga diperlukan konsentrasi tiap individu ketika pelaksanaan pembelajaran dan waktu pembelajaran secara daring lebih singkat dibanding ketika tatap muka langsung. Dikuatkan oleh Dewi $(2020$, p. 56) bahwa proses belajar dilaksanakan di rumah melalui pembelajaran daring/jarak jauh dilaksanakan untuk memberikan pengalaman belajar yang bermakna bagi siswa.

\section{KESIMPULAN}

Berdasarkan penelitian tindakan kelas yang Berdasarkan analisis dan pembahasan, dapat disimpulkan bahwa dengan penerapan model Problem Based Learning dapat meningkatkan hasil belajar siswa kelas VB SDN Wonotingal Kabupaten Semarang. Penerapan model Problem Based Learning akan memberikan pembelajaran yang bermakna bagi kehidupan sehingga dapat mengembangkan cara berpikir dan kreativitas dalam memecahkan suatu permasalahan dengan cara meningkatkan konsentrasi siswa. Untuk memaksimalkan pembelajaran, sebaiknya guru mempersiapkan terlebih dahulu pertanyaan yang akan digunakan baik dari segi bahasa maupun konten kalimat yang disesuaikan dengan tingkat pemahaman siswa uang akan memancing siswa untuk berpikir dan siswa sebaiknya lebih berkonsentrasi saat proses pembelajaran untuk memperoleh informasi lebih detail mengenai materi yang akan dipelajari.

\section{DAFTAR PUSTAKA}

Achmad, \& Wintala, S. (2015). Buku Induk Mahir Bahasa Dan Sastra Indonesia. Araska Publisher.

Dewi, W. A. F. (2020). Dampak COVID-19 Terhadap Implementasi Pembelajaran Daring Di Sekolah Dasar. Edukatif: Jurnal Ilmu Pendidikan, 2(1), 55-61. Https://Doi.Org/10.31004/Edukatif.V2i1.89

Panduan Penilaian Kurikulum 2013, (2016). Http://Ditpsd.Kemdikbud.Go.Id/WpContent/Uploads/2017/06/Panduan-Penilaian-Untuk-Sekolah-Dasar.Pdf

Evi, T., \& Indarini, E. (2021). Meta Analisis Efektivitas Model Problem Based Learning Dan Problem Solving Terhadap Kemampuan Berpikir Kritis Mata Pelajaran Matematika Siswa Sekolah Dasar. Edukatif: Jurnal Ilmu Pendidikan, 3(2), 385-395. Https://Doi.Org/10.31004/Edukatif.V3i2.314

Fakhriyah, F., Sumaji, \& Roysa, M. (2016). Pengaruh Model Problem Based Instruction Dalam Mengembangkan Kemampuan Berpikir Kritis Siswa Sekolah Dasar. Jurnal Konseling Gusjigang PGSD Universitas Muria Kudus, 2(1), 90-96. Https://Media.Neliti.Com/Media/Publications/107461-ID-ProfilKemampuan-Pemecahan-Masalah-Siswa.Pdf

Haryanti, Y. D. (2017). Model Problem Based Learning Membangun Kemampuan Berpikir Kritis Siswa Sekolah Dasar. Cakrawala Pendas, 3(2), 57-63.

Kirom, A. (2017). Peran Guru Dan Peserta Didik Dalam Proses Pembelajaran Berbasis Multikultural. Al Murabbi, 3(1), 69-80. Http://Jurnal.Yudharta.Ac.Id/V2/Index.Php/Pai/Article/View/893

Kurniaman, O., \& Noviana, E. (2017). Penerapan Kurikulum 2013 Dalam Meningkatkan Keterampilan, Sikap, Dan Pengetahuan. Jurnal Primary Program Studi Pendidikan Guru Sekolah Dasar Fakultas Keguruan Dan Ilmu Pendidikan Universitas Riau, 6(2), 389-396.

Kurniawati, A. (2018). Analisis Hasil Tes Evaluasi Pendidikan Pada Mahasiswa Ditinjau Dari Perbedaan Gender. Jurnal Ilmiah DIDAKTIKA, 19(1), 89-106.

Lestari, D. P., \& Astimar, N. (2020). Peningkatan Hasil Belajar Siswa Dengan Model Problem Based Learning Pada Pembelajaran Tematik Terpadu. ... Pembelajaran Inovasi, Jurnal Ilmiah ..., 2(2).

Murtono. (2017). Merencanakan Dan Mengelola Model-Model Pembelajaran Inovatif. Wade Group. Dinamika Pendidikan.

Nada, I., Utaminingsih, S., \& Ardianti, S. D. (2018). Penerapan Model Open Ended Problems Berbantuan CD 
2047 Peningkatan Hasil Belajar Siswa Sekolah Dasar Melalui Model Pembelajaran Program Based Learning Syarifa Rahma Amelia, Veryliana Purnamasari, Darsimah

DOI : https://doi.org/10.31004/edukatif.v3i5.747

Pembelajaran Untuk Meningkatkan Kemampuan Berpikir Kreatif Siswa Kelas IV Sd 1 Golantepus. Jurnal Pendidikan Sekolah Dasar, 4(2), 216-227. Https://Doi.Org/10.30870/Jpsd.V4i2.3856

Nafiah, Y. N., \& Suyanto, W. (2014). Penerapan Model Problem-Based Learning Untuk Meningkatkan Keterampilan Berpikir Kritis Dan Hasil Belajar Siswa. Jurnal Pendidikan Vokasi, 4(1), 125-143.

Octavia, W. A. H., Satrijono, H., Hutama, F. S., Haidar, D. A., \& Rukmana, L. P. (2020). Keterampilan Menulis Karangan Persuasi Siswa Dalam Pembelajaran Think Talk Write Dengan Media Poster Wilda. Keterampilan Menulis Karangan Persuasi Siswa Dalam Pembelajaran Think Talk Write Dengan, 1(2), 169-186.

Rahma, U. L., \& Priswati, R. (2019). Keterampilan Menyajikan Teks Persuasi Melalui Model Scaffolding Dengan Media Kartu Cerita Lingkungan Kita (Kartalita). Jurnal Profesi Keguruan, 5(1), 180-183. Https://Journal.Unnes.Ac.Id/Nju/Index.Php/Jpk

Rahmat, E. (2018). Penerapan Model Pembelajaran Problem Based Learning Untuk Meningkatkan Prestasi Belajar Ips. Jurnal Penelitian Pendidikan, 18(2), 144-159. Https://Doi.Org/10.23887/Jisd.V1i3.11997

Suardin, S., \& Andriani, W. O. L. (2021). Studi Komparatif Model Problem Solving Dengan Model Teams Games Tournament (Tgt) Terhadap Hasil Belajar Matematika Siswa Sekolah Dasar. Edukatif: Jurnal Ilmu Pendidikan, 3(1), 227-234. Https://Doi.Org/10.31004/Edukatif.V3i1.289

Susanto, A. (2016). Teori Belajar Dan Pembelajaran. Prenamedia Group.

Syupriyanti, L., Firman, \& Neviyarni. (2019). Pengaruh Media Audio Visual Interaktif Menggunakn Pendekatan CTL Dalam Pembelajaran Tematik Terpadu Terhadap Hasil Belajar Dan Motivasi Siswa Di Sekolah Dasar. Edukatif: Jurnal Ilmu Pendidikan, 1(3), 237-243.

Yunitasari, R., \& Hanifah, U. (2020). Pengaruh Pembelajaran Daring Terhadap Minat Belajar Siswa Pada Masa COVID 19. Edukatif: Jurnal Ilmu Pendidikan, 2(3), 232-243. Https://Doi.Org/10.31004/Edukatif.V2i3.142 